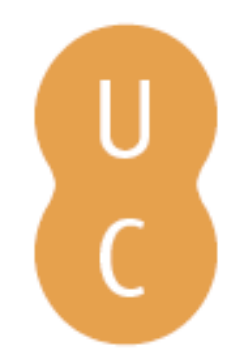

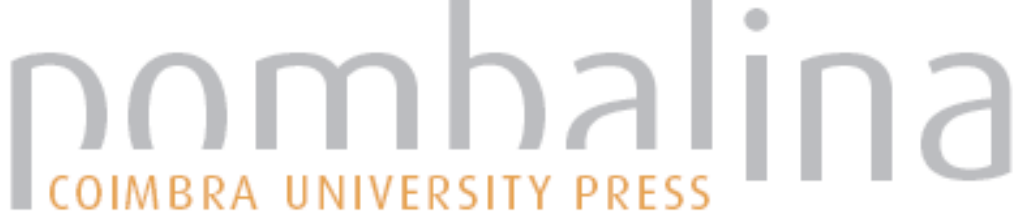

\section{O Oriente Mediterrânico e a Hispânia}
Autor(es):
Guerra, Amílcar
Publicado por: Imprensa da Universidade de Coimbra
URL persistente:
URI:http://hdl.handle.net/10316.2/36916
DOI:
DOI:http://dx.doi.org/10.14195/978-989-26-0954-6_6.2

Accessed : $\quad$ 26-Apr-2023 14:58:19

A navegação consulta e descarregamento dos títulos inseridos nas Bibliotecas Digitais UC Digitalis, UC Pombalina e UC Impactum, pressupõem a aceitação plena e sem reservas dos Termos e Condições de Uso destas Bibliotecas Digitais, disponíveis em https://digitalis.uc.pt/pt-pt/termos.

Conforme exposto nos referidos Termos e Condições de Uso, o descarregamento de títulos de acesso restrito requer uma licença válida de autorização devendo o utilizador aceder ao(s) documento(s) a partir de um endereço de IP da instituição detentora da supramencionada licença.

Ao utilizador é apenas permitido o descarregamento para uso pessoal, pelo que o emprego do(s) título(s) descarregado(s) para outro fim, designadamente comercial, carece de autorização do respetivo autor ou editor da obra.

Na medida em que todas as obras da UC Digitalis se encontram protegidas pelo Código do Direito de Autor e Direitos Conexos e demais legislação aplicável, toda a cópia, parcial ou total, deste documento, nos casos em que é legalmente admitida, deverá conter ou fazer-se acompanhar por este aviso.

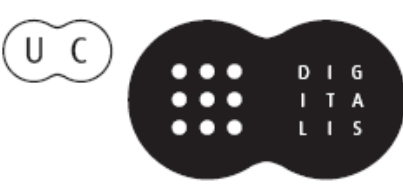


JOSÉ LUÍS BRANDÃO FRANCISCO DE OLIVEIRA (COORD.)

IMPRENSA DA

UNIVERSIDADE

DE COIMBRA

COIMBRA

UNIVERSITY

PRESS
HISTÓRIA DE
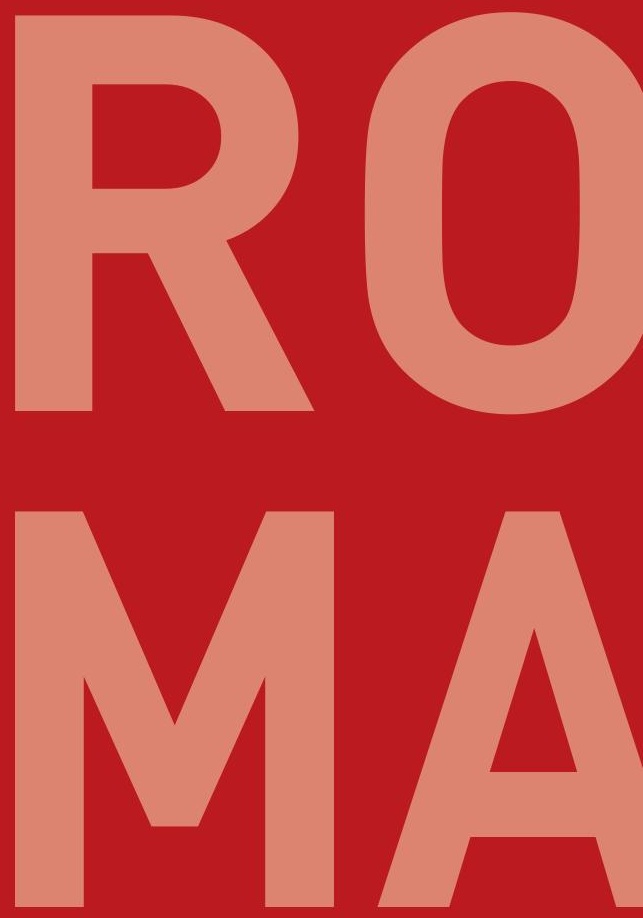

ANTIGA

VOLUME I

DAS ORIGENS À

MORTE DE CÉSAR 


\subsection{O ORIENTE MEDITERRÂNICO E A HISPÂNIA}

\section{Amilcar Guerra}

(Universidade de Lisboa)

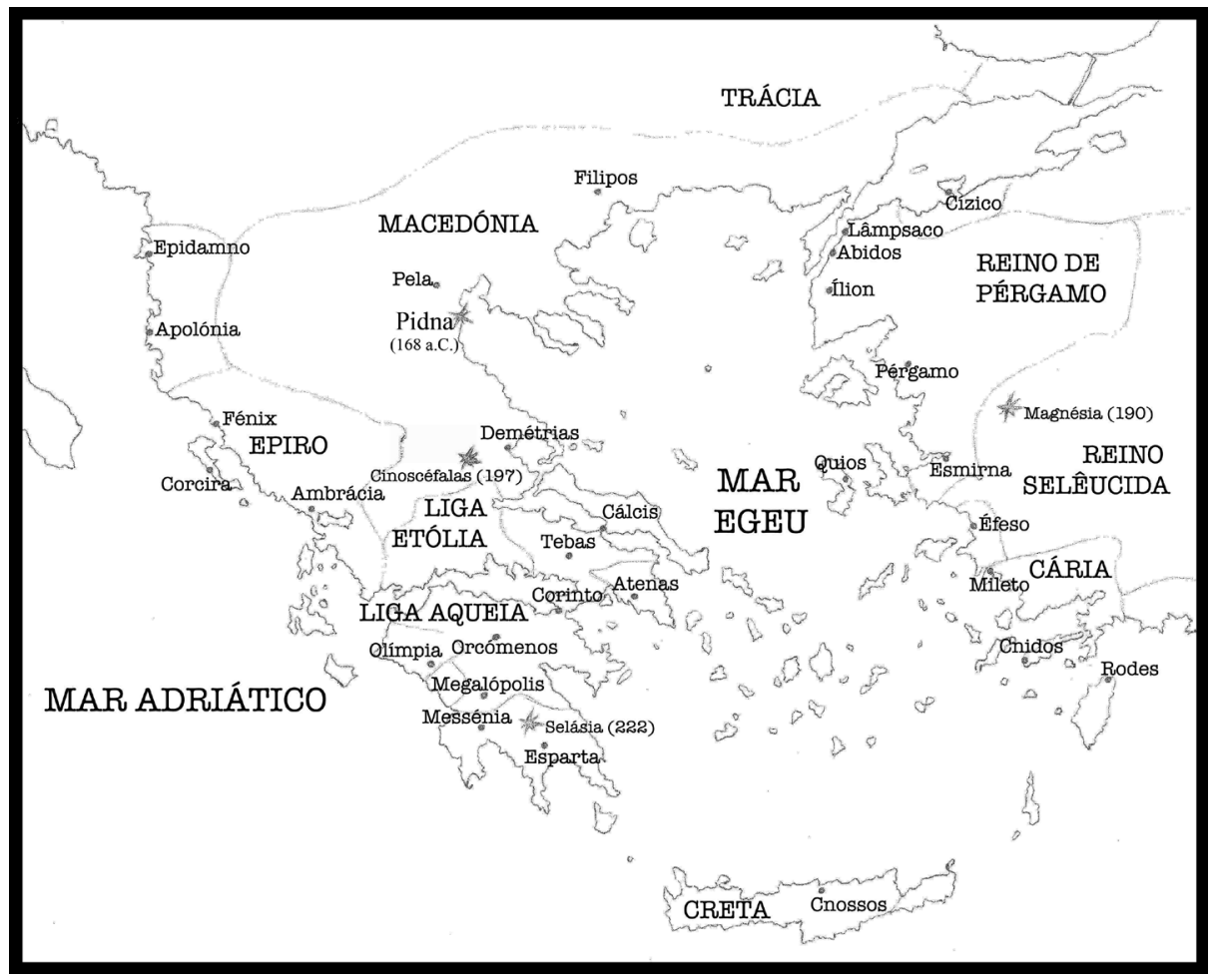

Fig. 1. Macedónia e Egeu c. 200 a.C. - por Fábio Mordomo 
Sumário. A política romana no Mediterrâneo oriental. As guerras ilíricas e macedónicas. A situação dos reinos helenísticos e da Grécia. Guerra com Antíoco III. Efeitos da batalha de Pidna. A evolução na política imperialista Romana. A progressiva subjugação da Grécia. A política romana na Hispânia: guerras com os Lusitanos e Celtiberos.

O processo de expansão do domínio romano revelou-se muito prolongado no tempo e as suas vicissitudes são bastante complexas. Embora o progresso da conquista romana não tenha obedecido a uma lógica de natureza geográfica, a melhor forma de o compreender reside na sua apresentação diferenciada consoante as regiões. É natural, pois, que neste capítulo a sequência cronológica seja quebrada. Deste modo, expõem-se separadamente as principais etapas da conquista romana em três áreas distintas (Ilíria; Grécia, seguida de Ásia Menor; e Hispânia) apresentando, em cada um destes apartados, uma breve síntese das vicissitudes da expansão romana nessas regiões, começando pela área ilírica.

Quando se tratam as motivações da intervenção romana nesta área, parte-se dos principais relatos ${ }^{1}$ que as fontes antigas proporcionam e das diferentes perspetivas que a historiografia sobre elas construiu. De um lado uma perspetiva construída sobre a óptica polibiana, cujo principal defensor é Holleaux (1930); do outro a visão de Apiano que encontra em Walser (1954) um dos mais conhecidos representantes. No essencial estas duas abordagens tradicionais opõe-se quanto à existência ou não, nesta fase inicial do processo, de uma política romana expansionista em relação ao mundo grego e ao Oriente $^{2}$. Isto é, se os conflitos ilíricos se limitavam a resolver um problema prático que se traduzia na ameaça à segurança e aos interesses dos itálicos nessa região; ou se visava objetivos mais amplos e ambiciosos, que mais tarde se tornam patentes ${ }^{3}$.

Nas páginas que se seguem não se encontra uma resposta unívoca a esta questão, mas podem vislumbrar-se os diferentes matizes da política externa

\footnotetext{
${ }^{1}$ As fontes clássicas essenciais correspondem a Plb. 2.2-12; 3.16; 3.18-19 e App. Ill. 2.7-8, apresentando substanciais discordâncias. Para uma análise comparativa destas duas fontes, v. Derow 1973.

2 Para uma síntese das perspetivas mais recentes sobre o imperialismo romano, v. Matingly 2011 13-22

3 Sobre a questão v. Walbank, 1963.
} 
romana em mudança, por força dos condicionalismos históricos muito variados que marcam a sua história.

\section{As Guerras Ilíricas}

No período que medeia entre a $1 .^{\mathrm{a}}$ e $2 .^{\mathrm{a}}$ Guerras Púnicas, Roma orienta

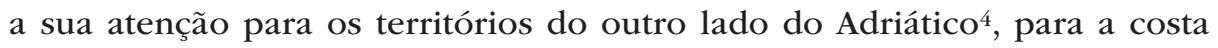
dálmata, área tradicionalmente afetada pelo flagelo da pirataria. Nesta região, onde vigorava uma fragmentação política consubstanciada na autonomia de pequenos poderes tribais, veio a constituir-se, na segunda metade do séc. III, um poder centralizado, de cariz monárquico ao qual presidia o rei Ágron. Esta unificação conferiu a esse reino ilírico um considerável poder militar sobre o qual se alicerçou uma política expansionista que afetou particularmente as vizinhas cidades gregas da Península Balcânica e quase todas as ilhas mais próximas. A situação tornou-se ainda mais preocupante para os estados da região quando a tradicional atividade da pirataria se incrementou, recebendo uma proteção desse reino, o que afetou fortemente o comércio e pôs em causa a segurança das cidades numa área cada vez mais extensa, não apenas as da Península Balcânica, mas também as da costa itálica5. Os perigos desta ameaça eram acrescidos pelo facto de o vizinho reino da Macedónia, tradicionalmente antagónico, ter optado, sob Demétrio II (239-229), por uma estratégia de amizade com o soberano ilírico, o que lhe valeu o apoio nos conflitos do reino macedónio contra a Liga Etólia.

\section{Primeira Guerra Ilírica}

Com a morte de Ágron (231), tomou a regência e deu continuidade à postura expansionista do seu marido Teuta (Plb 2.4.7), à qual o Estado

\footnotetext{
${ }^{4}$ Genericamente, v. Austin et alii ed. 1989 85-94; Gruen 1984 359-373.

5 Plb. 2.8.1-3; Harris 1979 195-197.
} 
Romano enviou uma embaixada $(229)^{6}$ a fim de pedir explicações sobre alguns dos efeitos concretos dessa política. Essa missão teria sido confiada, segundo a versão polibiana (Plb. 2.8.3), a dois irmãos Coruncânios, Gaio e Lúcio.

De qualquer modo e embora os relatos das fontes clássicas divirjam no que toca a vários aspectos concretos, atribui-se geralmente à morte de um embaixador romano ${ }^{7}$ a decisão de Roma enviar contra Teuta uma frota de 200 navios (Plb 2.11.1), entrando em conflito aberto com a monarquia ilíria e dando origem à $1 .^{a}$ guerra ilíria (229-228).

Estas forças navais prestaram auxílio a algumas cidades gregas do canal de Otranto (Corcira, Epidamno, Apolónia), que contavam apenas com um diminuto apoio das ligas etólia e aqueia, mas já não conseguiram impedir que a primeira delas tivesse sido tomada, ficando às ordens do grego Demétrio de Faros, aliado de Teuta. O advento da armada romana veio, todavia, ditar uma alteração radical da situação. Demétrio entregou Corcira e pôs-se do lado itálico, abandonando Teuta (Plb. 2.11.4), e esta retirou os seus navios sem combater, após a deditio a Roma das três cidades referidas. A intervenção romana foi concluída com a libertação do domínio ilírio de outras cidades gregas da região, entre elas Issa. Esta fase do conflito encerrar-se-ia com pedido de paz da rainha Teuta, o reconhecimento do protetorado romano na região de conflito e a aceitação de um limite para a ação ilíria, fixado na cidade de Lisso (atual Lezhë, Albânia) (Plb. 2.12.3). Desta forma, uma intervenção romana na região travou a pirataria e trouxe mais segurança, especialmente às cidades gregas dessa área que, sem o apoio de outros gregos e incapazes de enfrentar sozinhas o poder ilírio, passaram a depender da proteção da Urbe.

${ }^{6} \mathrm{Na}$ sua origem estaria, segundo a versão de Apiano (Ill. 2.7), um pedido de ajuda de Issa, ou mesmo a deditio desta (D.C. 12.33). Sobre a questão, v. Derow 1973; Gruen 1984361.

7 Segundo Plb. 2.8.12-13, teria sido assassinado um dos dois enviados romanos. No entanto, as fontes divergem sobre o número e a natureza das pessoas envolvidas. Sobre esta questão e a possibilidade de esta(s) morte(s) ter(em) sido uma invenção posterior v. Derow 1973 122-123; Gruen 1984 360-362. 


\section{Segunda Guerra Ilírica}

Se a intervenção de Roma tinha agradado a algumas cidades gregas, provocou uma reação oposta em outras, em particular no reino da Macedónia. Antígono Dóson, sucessor de Demétrio II, não viu com bons olhos a intervenção externa numa área estrategicamente importante para o seu reino e que constituía o acesso tradicional ao mar Adriático. Esta atitude não se devia apenas à sua aliança com os ilírios, mas também ao facto de ele ter retomado o conflito com as ligas etólia e aqueia, as quais tinham aceitado a intervenção dos romanos na região. Esta posição macedónia veio a contar igualmente com o apoio de Demétrio de Faros, o qual, por um conjunto de circunstâncias, assumiu o controlo do reino ilírico, pelo que essa comunhão de interesses se veio a materializar numa aliança entre ambos. Aproveitando o facto de Roma estar envolvida no conflito com os Gauleses e mais despreocupada com o que se passava nesta região, a Macedónia retomou, após a batalha de Selásia (222), o controlo sobre as cidades gregas e os ilírios voltaram às suas pretensões expansionistas e alargam o exercício da pirataria e do saque por todo o mar Adriático, desrespeitando o tratado de $228^{8}$.

Resolvida a questão gaulesa, Roma desencadeia várias ações destinadas a pôr cobro a esta situação. Numa primeira fase (221) restabelece o seu domínio no fundo do Adriático, combatendo a pirataria e garantindo o controlo da Ístria. Mais tarde (219) atacou diretamente Demétrio9, o qual, não podendo contar com o apoio da Macedónia, envolvida em sérios problemas sucessórios, foi derrotado. Depois de um ataque vitorioso à localidade ilírica de Dimalo, os Romanos dirigiram-se contra a ilha e cidade de Faros (atual Hvar, Croácia), que acabou por ser destruída (Plb. 3.19.12). A potência itálica retoma, desta forma, o seu domínio na região, nas vésperas da segunda guerra púnica.

${ }^{8}$ Plb. 3.16.2 aponta como causa próxima da guerra o facto de Demétrio ter passado a linha de Lisso com 15 navios. Sobre a muito discutida questão das origens deste conflito v. Eckstein, 1994.

9 Plb 3.18-19; Gruen 1984 170-173; 


\section{As Guerras Macedónicas e a anexação da Grécia}

A ação romana na região ilíria pôs em evidência um conflito de interesses entre Itálicos e Macedónios e provavelmente só problemas internos destes últimos impediram que eles atingissem um ponto de rutura. No entanto a questão ficou apenas adiada. Alguns anos mais tarde, Filipe $\mathrm{V}$, conhecendo os problemas que o ataque de Cartago colocava ao mundo itálico, considerou que esse seria um momento adequado para fazer valer as suas pretensões na região. Deste modo, em 215 chegou a um acordo com a potência púnica ${ }^{10}$, garantindo-lhe o seu apoio militar como contrapartida a uma posição favorável na causa ilírica. Ao tomar conhecimento deste acordo, Roma enviou uma frota para o canal de Otranto, a qual venceu facilmente Filipe quando este atacou as cidades costeiras da região, dando origem ao primeiro conflito aberto entre ambas partes.

\section{Primeira Guerra Macedónia}

A situação descrita revela-se complicada para Roma, pelo facto de se encontrar envolvida na guerra com Cartago ${ }^{11}$, que exigia um contingente superior, deixando deste modo espaço de manobra a Filipe, especialmente em terra. Perante estas dificuldades, a potência itálica desenvolveu igualmente uma ação diplomática junto da Liga Etólia, empenhando-a na continuação da disputa contra um inimigo comum, a Macedónia, oferecendo no início um apoio naval, mas aliviando progressivamente a sua comparticipação. Em consequência das muitas dificuldades que enfrentava, a Liga Etólia, vencida, aceitou um pacto com Filipe. Uma vez que lhe faltavam os meios para alimentar mais um conflito secundário, Roma acabou por trilhar o mesmo caminho, celebrando a paz

10 Discute-se a autenticidade da notícia que afirmava ter sido capturado Xenófanes com uma cópia deste acordo (Liv. 23.33.9-12; Plb 7.9) que geralmente se toma como verdadeira (Austin et alii 1989 96-97).

11 Vide atrás Monteiro, cap. $6.1 \S 3$. 
de Fenice (205), através da qual cedia uma parte substancial da sua influência na região ${ }^{12}$.

O conteúdo deste tratado, bem conhecido das fontes literárias, envolvia outras partes para além de Roma e da Macedónia: pelo lado desta, elementos da sua symachia; pelo lado itálico, alguns amici, a saber, Átalo de Pérgamo, Esparta, Élide, Messénia, o príncipe ilírico Pleuroto e, segundo Lívio, também Atenas e Ílion ${ }^{13}$. A historiografia tem sublinhado que esta relação de amicitia, embora não constituísse um vínculo que obrigasse a ajuda militar entre os estados, acabará por ser relevante no processo de conquista da Grécia, como se verá.

A situação na Grécia e no Oriente antes da $2{ }^{a}$ guerra Macedónia14

Importa sublinhar previamente que, com a vitória sobre Cartago, Roma muda de forma significativa a sua política expansionista: altera a sua perspetiva, o seu horizonte de domínio ganha uma outra configuração, uma outra dimensão geográfica, apontando de forma cada vez mais evidente para o controlo de todo o Mediterrâneo. Mas, se na sua parte ocidental o afundamento do poderio púnico deixava um campo aberto, aparentemente fácil, à expansão romana, na sua vertente oriental a realidade parecia mais complexa.

O que restava do "império de Alexandre" era uma realidade muito diversa e fragmentada, na qual emergiam claramente algumas entidades políticas dominantes: o poderoso Egito ptolemaico, com uma ampla área de influência que se estendia ao norte de África e à Ásia Menor; o reino selêucida, sucessor do império persa, que disputava com os Ptolomeus a Síria e as costas da Ásia Menor; e, por fim, a Macedónia, cujos interesses no Egeu entravam também em conflito com as pretensões egípcias.

\footnotetext{
12 Liv. 29.12.11-16; Baldson 1954 32-34; Austin et alii 1989 103-106.

13 Para uma explicação sobre a presença destes contratantes v. Baldson 1954 32-33.

14 V., em geral, Baldson 1954; Austin et alii 1989 244-261.
} 
Nos finais do séc. III, todavia, esta situação de algum equilíbrio, mas também de alguma tensão latente, foi alterada por um conjunto de perturbações internas que afetaram o Egito, acentuadas com a morte de Ptolomeu IV (204). Esta maior fragilidade do novo soberano lágida ocorria numa altura em que Antíoco III conferia maior solidez ao reino selêucida e acalentava a ideia de subtrair a Ásia Menor ao domínio egípcio. Por seu lado, a Macedónia já conseguira, com a paz de Fenice, uma situação de maior desafogo, o que lhe permitia retomar as suas tradicionais pretensões sobre o Egeu.

Uma vez que ambas potências (reino selêucida e Macedónia) partilhavam a mesma vontade de atacar o poderio lágida, acabou por se materializar esta ideia num acordo ${ }^{15}$ que previa uma repartição do domínio sobre as áreas até aí controladas por este inimigo comum. De um lado Antíoco veio satisfazer as suas ambições, conseguindo o domínio da Celessíria na passagem do séc. III para o II. Ao contrário, no caso da Macedónia o plano não se realizou da forma imaginada. Desde logo porque as ações empreendidas (tanto na parte setentrional do Egeu, na Trácia e na área dos estreitos, como no âmbito mais meridional, atacando a cidade de Samos) afetavam profundamente o comércio na região e prejudicavam fortemente os habitantes de Rodes, que do exercício dessa atividade no Egeu e no Mar Negro retiravam consideráveis proventos. Perante esta situação, os Ródios encetaram uma ação diplomática com a qual obtiveram o apoio de Átalo I, de Pérgamo, reino que se sentia também muito afectado pelas movimentações macedónias: Filipe atacou Samos, foi derrotado em Quios, assediou Mileto, foi bloqueado em Bargylia ${ }^{16}$. Precavendo futuras complicações da situação, as duas aliadas tomaram a iniciativa de pedir ajuda a Roma, envolvendo-a nesta questão.

O senado decidiu não entrar imediatamente no conflito, mas preferiu enviar uma delegação de três elementos à Grécia para analisar a situação, de forma a tomar depois a atitude mais adequada. Aparentemente, a sua missão era tentar que o conflito entre as partes se não desenvolvesse ou

15 A existência deste "pacto secreto" foi contestada por Magie 1939. Para uma breve síntese sobre a questão, com bibliografia anterior, v. Grainger 2002 20-21.

16 Para uma síntese destas movimentações v. Austin et alii 1989 252-254. 
então, se esse plano falhasse, participar na guerra. Por isso, quando se confrontou com um conflito declarado entre a Macedónia e Atenas (esta apoiada por Pérgamo) os enviados de Roma expuseram a Filipe o conteúdo da decisão do senado17. Os termos em que este "pedido" foi feito não são muito claros, mas podem ter revestido um caráter de intimação, o que teria provocado uma reação adversa, conduzindo de imediato ao ataque a Atenas, mas também à cidade asiática de Abido (201), importante porto da zona estreita do Helesponto.

Um membro da missão romana enviada a Abido teria apresentado, em vão, um ultimato aos Macedónios, impondo o cumprimento de uma série de exigências, em especial: não atacar as cidades gregas nem os interesses egípcios; reparar os prejuízos causados a Pérgamo e aos Ródios. Na realidade, a decisão de Roma entrar em guerra era inevitável. De qualquer modo, a diplomacia itálica teve de agir com habilidade de forma a garantir uma neutralidade do reino selêucida, o que lhe permitia uma vantagem considerável neste conflito, uma vez que, na prática, isolava Filipe, dado que a maioria dos estados gregos preferiu aguardar pelo desenvolvimento das hostilidades para tomar abertamente posição.

A historiografia questiona-se sobre os reais motivações de Roma ao envolver-se directamente nesta região. A decisão, no plano jurídico, assentava nos termos da paz de Fenice (205), na qual se consagrava Pérgamo como amicus et socius, o que justificava, o envio de auxílio militar. Mas esta explicação está longe de ser totalmente satisfatória, tendo em conta a amplitude da intervenção que ultrapassa em muito o simples apoio a Pérgamo e aos seus interesses. A explicação da historiografia é diversificada: o respeito pelos acordos ou a admiração e simpatia pela cultura grega confrontam-se com o reconhecimento de uma vontade de domínio, de um sentimento imperialista de matizes diversos, desde o mais disfarçado (de natureza preventiva), ao mais declarado e agressivo, movido pela sede de poder e de dinheiro da elite ${ }^{18}$.

$17 \mathrm{O}$ seu conteúdo é resumido em Plb 16.27.2-3. Sobre as movimentações prévias ao ataque a Abido v. Austin et alii 1989 255-259.

18 Sobre as diferentes perspetivas tradicionais na abordagem historiográfica do tema v. Scullard 1980 224-226. 


\section{Segunda Guerra Macedónica}

Roma atacou diretamente uma Macedónia isolada e simultaneamente pressionada por outros (em especial pela Liga Etólia), sem os seus tradicionais apoios, com um exército inicialmente comandado pelo cônsul Sulpício Galba, depois pelo impreparado Vílio e, por fim, por Tito Flamínio, que entrou com sucesso em território inimigo (198). A pressão de Roma conduziu progressivamente as cidades gregas a aceitarem, pela via diplomática, um pacto de amizade, o que veio inclusivamente a acontecer com a própria Liga Aqueia, aliada de Filipe. Deste modo, o soberano macedónio é pressionado a um entendimento com Roma, mas as condições propostas por esta não obtêm o acordo da outra parte, pelo que tudo se encaminha para novo confronto, numa altura em que se assumem como pró-romanas cada vez mais cidades gregas, entre elas Esparta. O recontro decisivo acabou por se dar na Tessália, nas colinas com o sugestivo nome de Cinoscéfalas, a respeito do qual se costuma sublinhar a superioridade da estratégica concebida por Flamínio ${ }^{19}$.

Perante esta derrota, Filipe teve de aceitar condições de paz bem mais gravosas, que implicavam, entre outras cláusulas, a perda da sua influência nos territórios gregos (balcânicos, insulares ou asiáticos) por ela antes controlados. Na perspetiva que interessava a Roma, os Gregos tinham-se livrado da opressão macedónia e restituídos à sua condição de livres, dispensados do tributo e, como o senado pretendia e a tradição jurídica romana gostava de sublinhar, regulados "pelas suas próprias leis» ${ }^{20}$. Esta circunstância, formalmente anunciada pelo próprio Flamínio nos Jogos Ístmicos (196) ${ }^{21}$, não representava necessariamente uma maior autonomia das cidades gregas, condicionadas pela vontade e poder dos grandes reinos helenísticos, ou limitadas pelas obrigações decorrentes da sua associação em ligas. No entanto, o tratado com a Macedónia implicava que esta prescindisse do controlo militar sobre as cidades

\footnotetext{
19 Liv. 33.7-10; Plb. 18.20-32; sobre o tema v. Hammond 1988.

20 Estes são os termos em que se exprime o senatus consultum de 196 (Liv. 33.32.5).

21 Sobre o valor propagandístico desta ato v. Wash, 1996.
} 
gregas e a presença romana visava garantir a proteção dos gregos contra este reino ou qualquer outro. Modificava-se, deste modo, a tradição de conflituosidade interna que marcou a História da Grécia e conseguia-se uma liberdade garantida por uma potência exterior, circunstância que encerrava em si algo de contraditório.

Colocava-se neste momento ao Estado Romano uma questão pertinente que decorria da precária estabilidade que oferecia a situação política na Grécia: se Roma deixasse os gregos entregues à sua liberdade, tornava-se claro, mesmo para os maiores admiradores da sua história e cultura, como Flamínio, que o ressurgimento de interesses particulares reconduziria a uma situação de conflito e mergulharia a região no caos. Por isso parecia mais sensato, na perspetiva de uma política exterior realista, manter uma presença efetiva que assegurasse uma pacificação geral, ainda que forçada, pelo menos até que os perigos de instabilidade se considerassem afastados.

Efetivamente, nem tudo correu da forma mais tranquila. Pouco tempo após a derrota de Filipe gerou-se um conflito com Nabis de Esparta $^{22}$ que conduzirá a nova etapa das relações com o mundo grego. Nos últimos tempos, este tirano tinha alterado, de acordo com as suas conveniências imediatas, o alinhamento com Filipe, a quem antes oferecera Argos, aceitando agora a proteção de Roma. Naturalmente, perante a derrota da Macedónia recolocou-se o problema da situação de Argos, a qual foi também reclamada, pela Liga Aqueia, que nunca aceitara o domínio de Esparta e da Macedónia sobre ela, posição que Roma apoiou. A questão foi discutida em âmbito pan-helénico com a presença romana, tendo-se decidido mover guerra a Esparta, que não pôde resistir às forças associadas do mundo grego (em que participou inclusivamente a Macedónia) e romano. Na celebração da paz, em que interveio Roma, esta beneficiou a Liga Aqueia, ao atribuir-lhe Argos e o controlo de toda a costa lacónia (Liv. 34.24.6.). Muitos dos gregos, e particularmente a Liga Etólia, questionaram, com alguma pertinência, as decisões de Flamínio, que tratava de forma muito diferenciada as distintas partes gregas, intervindo, com manifesta parcialidade, nos

22 Sobre as pretensões de Esparta e as suas consequências v. Gruen 1984 448-455. 
assuntos internos gregos. Deste modo parecia pouco credível a vontade romana de contribuir para uma verdadeira libertação da Grécia.

Por isso, constitui uma surpresa para muitos gregos, o facto de a cidade latina ter ordenado, em 194, a retirada de todas as suas forças militares da Grécia ${ }^{23}$, tal como tinha defendido com convicção a próprio Flamínio, um dos que tinham sustentado com mais consistência uma linha política de respeito pela autonomia grega. Com esta orientação da diplomacia e política exterior, Roma recuperava o desgaste que tinha sofrido com a sua contínua intervenção na região e contrariava a ideia de que a sua intervenção era interesseira e constituía uma forma de preparar a futura anexação da Grécia. Recuperava, com isso, o respeito de muitos gregos e dava nova vida à sua diplomacia na região. Mas a situação iria mudar em breve, não apenas devido aos crónicos conflitos dos estados gregos, mas também em consequência da política romana na Ásia Menor, em especial dos conflitos em curso com o reino selêucida.

Roma e Antioco 24

No jogo político e diplomático, tanto Roma como Antíoco III, encararam os seus interesses como coincidentes no que se referia à posição perante o poder do reino Macedónio. Este soberano oriental alimentava a ideia de substituir esta última potência na região, dando cumprimento a um desejo de restaurar o antigo poder de Seleuco I, o fundador do seu império. Roma, por seu lado, procurou evitar um conflito com este monarca ${ }^{25}$, mantendo-se distanciada tanto perante as disputas dele com a Macedónia, como na sua intervenção na Celessíria.

Esperando a mesma atitude, o selêucida empreendeu algumas campanhas que afetaram aliados de Roma: primeiro atacou territórios controlados pela

23 Austin 1989 277; Grainger 2002 125-127.

${ }^{24}$ As fontes clássicas essenciais são Liv. 33.19-20, 31, 34, 38-41, 43-45; 34.57-60. Plb. esp. livros 18, 21, 26-31. Para uma análise historiográfica mais recente v. Grainger 2002.

25 Sobre as relações entre Roma e Antíoco antes do conflito v. Grainger 2002 5-30. 
Macedónia e Egito e depois os interesses de Rodes, tendo esta reclamado junto do monarca pelos prejuízos que lhe causava essa ação militar (Liv. 33.20). Apesar disso, Antíoco conseguiu evitar que estas operações conduzissem a um conflito, talvez porque Roma estava mais empenhada em resolver a situação na Grécia. No entanto, quando se constatou que, celebrada a paz com Filipe da Macedónia, cidades que este prometeu libertar foram ocupadas pelo reino selêucida e algumas delas se puseram sob a proteção de Roma ${ }^{26}$, algo se alterou. A posição desta a respeito da acção de Antíoco manifestou-se, de forma algo enviesada, através da proclamação de Corinto, no qual se impunha explicitamente a libertação das cidades gregas da Ásia Menor e se proibia qualquer ação em território europeu, e o mesmo se fez saber aos enviados do rei selêucida. Este, assumindo a exigência como um ato provocatório, respondeu instalando-se em Lisimaqueia ${ }^{27}$, uma cidade da Trácia. A atitude de Roma confinou-se nesta fase ao envio de uma delegação a esse soberano asiático ${ }^{28}$, confirmando as exigências do senado, mas estas não alteraram a posição de Antíoco. Para além de não reconhecer legitimidade à potência ocidental no que tocava a decisões sobre as duas áreas em causa, respondeu com uma série de ações diplomáticas e argumentos favoráveis ao seu ponto de vista. Ainda que nenhuma das partes desejasse entrar em conflito aberto, a tensão aumentava, mas foi visivelmente atenuada nesta fase pela decisão de Roma retirar as suas tropas da Grécia, o que foi interpretado pelo soberano selêucida como um ato de recuo ou pelo menos de desanuviamento nesta guerra de argumentos. No entanto, a linha defensora de uma atitude mais musculada no Oriente viu o seu representante, Cipião Africano, ser eleito para o consulado (194), resultado para o qual contribuiu certamente o facto de Antíoco ter acolhido Aníbal na sua corte. Apesar disso, o conflito jogava-se apenas no plano diplomático: enquanto os Romanos aumentavam as suas exigências, o soberano oriental

${ }^{26}$ Sob a atividade diplomática de Esmirna e Lâmpsaco e as suas consequências v. Grainger 2002 58-68.

27 Antíoco encontrou desabitada e quase todo em ruínas (Liv. 33.10), tendo mesmo promovido a sua reconstrução (Liv. 33.38.10-14; 33.40; Grainger 2002 70-72).

$28 \mathrm{O}$ encontro das partes dá-se precisamente em Lisimaqueia (Liv. 33.39.2). Sobre os múltiplos aspetos relacionados com ela v. Grainger 2002 76-97. 
reafirmava a sua vontade de chegar a um acordo aceitável para ambas as partes, o qual, no entanto, foi sendo protelado.

Este frágil equilíbrio veio a alterar-se com o evoluir da situação na Grécia, onde a Liga Etólia alimentava os sentimentos antirromanos, contando com o apoio de Nábis, Filipe e Antíoco. Destes, todavia, apenas o primeiro se dispôs logo a uma ação concreta. Entretanto, na Urbe os embaixadores sírios foram informados de uma nova formulação das exigências que demonstraria a boa vontade do povo romano: o monarca selêucida deveria optar entre renunciar à sua influência na Europa, fazendo o mesmo Roma em relação à Ásia; ou, em caso contrário, aceitar que a potência ocidental desenvolvesse as suas relações de amizade com as cidades gregas desta região. A resposta traduziu-se na decisão de Antíoco intervir na Grécia em apoio da Liga Etólia, a quem prestou o seu auxílio. Abre-se, desta forma, o caminho a um conflito direto entre as duas partes, numa situação em que ambas se sentiam obrigadas a defender os seus aliados.

O monarca selêucida, ao enviar uma pequena força militar, parece ter avaliado mal a dimensão das forças antirromanas, que se manifestaram incapazes de suster o poderoso exército que representava a Liga Aqueia, a Macedónia e Roma. O primeiro recontro deu-se na famosa passagem das Termópilas e, perante o fracasso da sua resistência em Naupacto, a Liga Etólia acabou por se render.

Estes acontecimentos vieram dar argumentos à fação romana mais dura, associada aos Cipiões, e justificaram, depois dos primeiros recontros vitoriosos, a recusa de um tratado de paz com Antíoco nos termos propostos em 196, exigindo-se, neste momento, a sua retirada para lá do Tauro. Ao recusá-la, o monarca sírio fazia depender a decisão dos confrontos militares, que acabaram por ser favoráveis aos Romanos, comandados por Gneu Domício Aenobarbo e apoiados por Pérgamo, em Magnésia de Sipilo ${ }^{29}$. A paz celebrou-se no ano seguinte, na cidade frígia de Apameia, sendo as suas condições bem conhecidas ${ }^{30}$ : no essencial o reino selêucida ficava limitado pelos rios Tauro e Halis e punha-se termo,

\footnotetext{
29 Sobre este conflito v. Liv. 38.37-44; App. Syr. 30-36; Grainger 2002 307-327.

30 Liv. 38.38-39; Plb. 21.45; App. Syr. 39; MacDonald 1967.
} 
com uma série de exigências, a qualquer pretensão deste ao controlo do mundo helenizado e do Mediterrâneo oriental.

Estes sucessos não implicaram de imediato o controlo de Roma sobre os territórios conquistados, mas foram Pérgamo e Rodes, os seus aliados, a retirar deles um benefício direto. Cada uma delas aceitou o acordo estabelecido com o Estado Itálico sobre a administração da parte que lhes tocava, porém a mais favorecida era a primeira delas, que herdava uma boa parte do domínio selêucida ocidental e passava a receber tributo das cidades que dele fizeram parte.

Enquanto isto se passava na Ásia Menor, na Grécia os Romanos e seus aliados venciam e impunham duras condições à Liga Etólia, privando-a da autonomia na condução da política externa; ao passo que a Liga Aqueia passava a ocupar um papel preponderante.

Desta forma, a paz de Apameia desenhava uma nova configuração política desta região, emergindo não apenas o protetorado romano estendido à Ásia Menor, mas também o peso das novas potências que se consolidavam ${ }^{31}$ sob a sua proteção: a Liga Aqueia, Rodes e Pérgamo. Este reino, onde pontificava Eumenes, conduziu uma política expansionista ${ }^{32}$ contra Prúsias da Bitínia que contou, inicialmente, com o apoio de Roma; no entanto, ao solicitar ajuda para enfrentar o Ponto, recebeu uma resposta negativa. Algo de similar aconteceu quando o Estado Itálico deu razão às cidades lícias que se queixavam de Rodes ${ }^{33}$.

Na Grécia a situação revelou-se mais grave, uma vez que a Liga Aqueia depois de anexar todo o Peloponeso, abafou brutalmente as revoltas de Esparta e da Messénia, perante a impotência das embaixadas romanas que solicitavam o fim desta violência. Constata-se, deste modo, que a potência itálica procura desenvolver a sua política que nem sempre coincide com os interesses particulares dos seus aliados, os quais, em algumas circunstâncias, constituem um verdadeiro motivo de preocupação para o Estado Romano.

31 Liv. 37.56.1-6; Plb 24.45; 24.48.

32 Sobre a política de Eumenes II nesta fase v. Austin 1989 324-328.

33 As cidades lícias reclamavam a condição de aliadas de Rodes e não de submetidas, pretensão à qual Roma, sem fundamento, terá dado resposta favorável (Austin et alii 1989 302 cfr. Plb 25.4.5 e Plb 21.46.8; 22.5.4). 


\section{Terceira Guerra Macedónia}

Entretanto, na Grécia, são os problemas causados pela Macedónia que assumem maiores proporções. Sonhando reconstituir o seu antigo poderio, Filipe V anexou primeiro, com o beneplácito de Roma, territórios do norte da Grécia e, logo de seguida, por sua iniciativa, as cidades de Aino e Maroneira, na Trácia34. Este último movimento militar suscitou uma reclamação de Pérgamo perante o Estado Romano, uma vez que esses territórios lhe tinham sido atribuídos pela paz de Apameia. Embora tivesse retirado por pedido do senado, acabou por massacrar os habitantes de Maroneia, o que teve consequências na sua imagem perante Roma. Através do seu filho, Demétrio, que desenvolvera uma amizade com círculos políticos da Urbe, o soberano macedónio procurou demonstrar a sua fidelidade, mas um conjunto de intrigas conduziu ao assassinato ${ }^{35}$ daquele que os Romanos gostavam de ter visto como seu sucessor. Esta circunstância levou ao trono o filho mais velho de Filipe, Perseu, o qual deu seguimento a uma política de afirmação do seu reino no contexto grego, aproveitando as dificuldades por que muitas cidades passavam. Mesmo que não fosse essa a sua intenção, acabou por assumir o papel de representante da corrente antirromana, situação para a qual contribuiu igualmente a ação de Eumenes, em manifesto antagonismo ao novo rei da Macedónia. O soberano de Pérgamo, depois de várias queixas, chegou a expor ao senado (172) o rol de agravos infligidos por Perseu ${ }^{36}$, o que terá constituído um elemento importante para decidir uma atuação do Estado Romano, guiada pela nova orientação da política romana para o Oriente, mais interventiva.

Roma iniciou as hostilidades com um exército impreparado, acabando por ser derrotada, o que lançou muitos gregos na incerteza quanto à atitude a tomar. Alguns dos tradicionais aliados de Roma, chegaram a

${ }^{34}$ Liv. 39.24.6-9; 39.27.7-10; Hammond; Walbank 2001 456-457.

35 Sobre episódio, que suscitou diversas considerações sobre o ambiente palaciano da Macedónia e o comportamento de Filipe v. Liv. 40.24.4; Plb. 23.10.12; D.S. 29.25; Hammond; Walbank, 2001 471-472.

$36 \mathrm{O}$ discurso, transmitido em Liv. 42.11-13, e que teria impressionado os senadores, considera-se genericamente credível (Hammond; Walbank 2001 498). 
propor uma reconciliação entre os contendores, o que foi mal interpretado por Roma. Esta, convicta da sua superioridade, organizou em 168 uma nova expedição mais consistente, comandada por Emílio Paulo, que acabou por derrotar Perseu em Pidna.

Roma altera substancialmente, a partir daqui, a sua postura em relação ao Oriente: enquanto até agora procurava manter-se como um estado protetor e regulador, mas que dava margem a uma grande liberdade das entidades sob o seu controlo; passa agora a assumir uma atitude imperialista, em que a sua hegemonia se orienta para a defesa dos interesses de Roma, eliminando os antigos centros de poder que com o seu consentimento e apoio se tinham desenvolvido. Por isso, todas as regiões e reinos do Oriente viram a sua situação alterar-se de forma mais ou menos substancial ${ }^{37}$.

A mais sacrificada foi, naturalmente, a Macedónia, que perdeu a sua identidade ao ser fragmentada em várias entidades forçadas ao isolamento. Mas também a Ilíria e o Epiro, que se tinham posto do lado desse reino agora desfeito, foram duramente castigados. O resto da Grécia passou momentos difíceis, em especial devido a um clima de delação que lançou uns gregos contra o outros e motivou represálias de Roma sobre muitas regiões e pessoas, agravando as situações de miséria e de disputas internas. Uma exceção ganha corpo em Atenas, que viu compensado o seu alinhamento com Roma com o controlo do porto de Delos, famoso como plataforma do mercado escravo. ${ }^{38}$

Por outro lado, a circunstância de Rodes ter apelado a um entendimento entre Roma e a Macedónia foi invocada como motivo da hostilidade por parte da Urbe. Viu, por isso, os seus territórios desmembrados e assistiu ao desenvolvimento de um porto-franco em Delos, o que conduziu ao progressivo afundamento da prosperidade comercial ródia ${ }^{39}$, para além das consequências no aumento da pirataria. Pérgamo não só viu recusada ajuda no combate à sublevação dos Gálatas como sofreu

37 Para as transformações na política e estratégia expansionista romana nesta fase $\mathbf{v}$. Austin et alii 1989: 46

38 Str. 10.5.4; Rauh 1993: 43-52.

39 Para uma análise do declínio de Rodes após 164 e da ascensão de Delos v. Berthold $2009^{2} 202-212$. 
uma ofensiva diplomática contra os seus interesses, situação difícil de prever alguns anos atrás.

Por fim, as relações com o reino selêucida sofreram uma evolução substancial: Antíoco IV, que tinha sido educado em Roma, contando aí com alguns amigos, desenvolveu algumas ações militares que o colocaram na situação de controlar o Egito; e ainda que o senado não tenha interferido até aí, decidiu responder a um pedido do soberano lágida, enviando Popílio Lenas. Estas duas personagens, velhos amigos, dão corpo a um episódio famoso ${ }^{40}$, no qual se percebe como um ultimato romano força o soberano sírio a abandonar o Egito. A partir daí vai-se acentuando o declínio do reino selêucida, cada vez mais longe do seu antigo esplendor, cada vez mais perto do fim.

A orientação que a política externa romana vinha a seguir desemboca inevitavelmente, mais tarde ou mais cedo, na submissão efetiva de todos estes territórios. Começa, naturalmente, pela Grécia, onde alguns acontecimentos vieram demonstrar a instabilidade crónica deste território sob o seu controlo, justificando um domínio de perfil bastante mais duro. A Macedónia proporcionou a razão para uma nova intervenção militar quando Andrisco, um personagem aventureiro que se faz passar por elemento da família real, conduz uma rebelião ${ }^{41}$ que concitou alguns apoios. Este breve episódio, que acabou em derrota, motivou a criação da província romana da Macedónia e significou o fim do reino e da sua já muito frágil autonomia.

Os últimos acontecimentos que põem termo à pouca margem de manobra de que os gregos ainda gozavam manifestam-se na dissensão gerada no âmbito da Liga Aqueia. Um conflito de fronteiras entre Esparta e Megalópole levou Roma, em última instância e já cansada dos constantes problemas a que tinha de acorrer, a decretar a independência de importantes cidades integradas nessa confederação, conduzindo-a ao seu fim. A raiva dos Aqueus acabou por se voltar contra Esparta, mas o exército romano submeteu os revoltosos, saqueou e destruiu Corinto $(146)^{42}$, encarando essa ação mais brutal como um exemplo para outros.

\footnotetext{
${ }^{40}$ Liv. 45.10; Plb. 29.27; Austin 1989 344-345.

41 Vell. 1.11.1-2; Flor. Epit. 1.30.3; D.S. 32.15.1-2.

42 Plb. 38.3-5; 39.13; Str. 8.6.23; Paus. 7.15.1-16.8; Gebehard; Dickie 2003 261-265.
} 
Com este episódio se assinala habitualmente o fim do processo de submissão da Grécia. Exceção feita à Macedónia, manteve-se aqui uma situação de alguma autonomia política, sempre sob o patrocínio, mais ou menos tolerante, de Roma. O seu estatuto mudará quando se reconstruir Corinto, em 44 , que se converterá na capital da nova província da Acaia.

\section{A conquista da Hispânia}

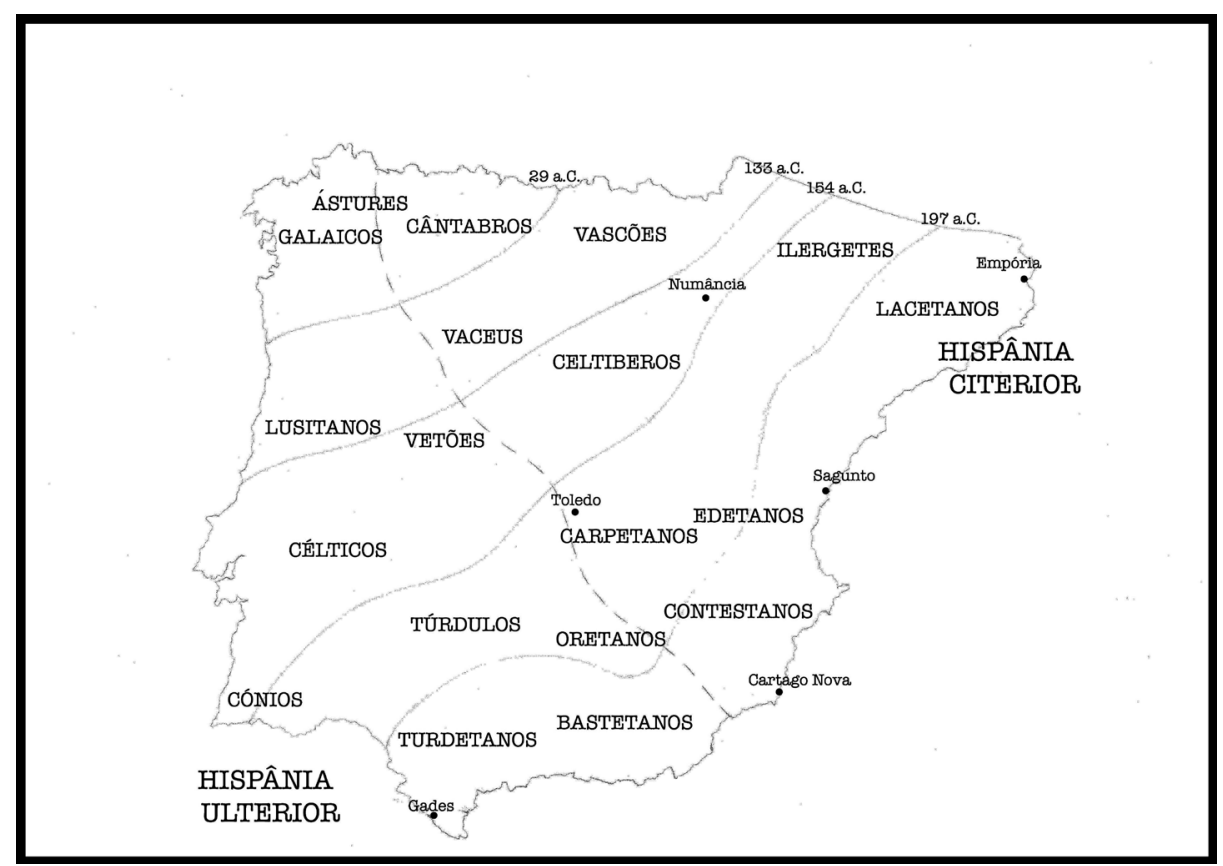

Fig. 2. Fases da conquista da Hispânia - por Fábio Mordomo

A expansão romana no lado oposto do Mediterrâneo é indissociável da segunda guerra púnica e dos conflitos que opõem Roma a Cartago ${ }^{43}$,

43 Vide atrás Monteiro, cap. $6.1 \$ 3$. 
a potência que controlava o extremo ocidente da Europa ${ }^{44}$. Este domínio da potência norte-africana, corolário de uma presença precoce de fenícios nesta região, foi seriamente ameaçado ao longo daquele conflito. No entanto, a forte presença militar e a iniciativa diplomática dos Bárcidas mantiveram-se bem ativas na Hispânia, mesmo quando Aníbal decidiu passar os Alpes ${ }^{45}$. Por seu lado, estratégia de Roma compreendia, para além da defesa da Itália, o ataque aos interesses inimigos na Península, sob o comando de Gneu Cornélio Cipião, que desembarcou em Emporion nos finais do verão de $218^{46}$. No ano seguinte juntou-se-lhe o seu irmão Públio, com um novo contingente, desenvolvendo ambos uma ação destinada a consolidar o domínio de Roma a norte do Ebro, na qual obtiveram sucesso ${ }^{47}$. No entanto, na continuidade destas operações mais para sul, apesar de progressos até terras turdetanas, acabaram por ser vencidos e $\operatorname{mortos}^{48}$ (211), o que obrigou a recuo das posições romanas até àquele mesmo rio. No final do ano seguinte, é enviado outro distinto membro da influente família dos Cornélios Cipiões, filho e homónimo do Públio que perdera a vida em campanha.

Depois de se informar sobre a situação no terreno, empreendeu um audacioso e bem-sucedido ataque ao centro do poder púnico em território hispânico, Carthago Nova ${ }^{49}$, debilitando seriamente a posição inimiga. As fontes sublinham a inteligente medida tomada pelo general romano de libertar os reféns indígenas capturados, ganhando desta forma um considerável prestígio perante as gentes locais ${ }^{50}$. Uma outra vertente da estratégia residiu no ataque a uma das grandes fontes de rendimento

44 Para as questões relacionadas com esta primeira fase da conquista v., em geral, Richardson 1986; Roldán Hervás, 1988; Keay 1988; Roldán Hervás 2001; Quesada 2009.

45 Roldán Hervás 1988 36-37.

46 Plb 3.76.1; Liv. 21.60.1-2; Roldán Hervás 198837.

47 Normalmente não se considera credível a versão de Lívio (22.20.3-6), segundo a qual as incursões romanas teriam atingido Carthago Nova e Loguntica e até o interior da Hispânia (Kahrsted 1916 425; Roldán Hervás, 1988 38-39; contra Schulten 1935 66). Também o ataque vitorioso a Sagunto, narrado em Plb. 3.97-99, seria devido a uma antecipação indevida de factos (Roldán Hervás 1988 39).

48 Liv. 25.36.12-14; Flor. Epit. 1.22.36; App. Hisp. 16.

49 Para uma síntese atual sobre esta ação militar v. Fernández Rodriguez 2005 40-71.

${ }^{50}$ A narrativa polibiana centra-se em particular no sugestivo caso do régulo Andobales, a quem Cipião devolve as filhas e com o qual celebra um pacto (Plb. 10.38), tomando-o como exemplo da sua ação diplomática. 
dos Cartagineses, os recursos mineiros. Depois de garantir o controlo das importantes minas de prata próximas de Carthago Nova, os exércitos foram apontados à região do Alto Guadalquivir, visando o acampamento de Asdrúbal, que segundo Políbio, "se encontrava na região de Cástulo, junto à cidade de Baecula51, não longe das minas de prata" (Plb. 10.38.7).

As dificuldades dos cartagineses em suster o avanço romano foram acentuadas ainda pelos pedidos de auxílio vindos de Itália, ao qual se respondeu com o envio de um contingente às ordens de Asdrúbal. $\mathrm{O}$ apoio aos generais cartagineses na Hispânia advinha agora especialmente de Lusitanos e Celtiberos, insuficiente para travar o avanço de Públio Cornélio Cipião sobre o vale do Guadalquivir, ou de Silano, seu lugar-tenente, sobre a Celtibéria. A pressão de Cipião acentuou-se e conduziu a um confronto decisivo com as forças púnicas (207), ocorrido em Ilipa52 (Alcalá del Río, Sevilha). Como último sinal, Gades, a mais importante plataforma comercial do Atlântico, antes ponto de apoio dos Cartagineses, decidiu entregar-se aos Romanos sem resistência (206). Desta forma Roma teria "libertado" a Península Ibérica dos Púnicos, assegurando o controlo de toda a faixa costeira levantina e meridional.

Um dos segredos de Cipião residiu na sua grande habilidade diplomática, aproveitando-se da circunstância de Cartago submeter as comunidades locais a duras condições. No entanto, com o fim da ameaça púnica na Hispânia e com o aumento das dificuldades de guerra em outros cenários, o chefe romano regressou a Itália e sua experiência nem sempre foi seguida pelos seus sucessores. Implanta-se, em geral, uma política repressiva e de exploração das populações e dos seus recursos, cujos contornos se conseguem entrever em casos como o de Lêntulo ${ }^{53}$, que se apresenta em Roma com ingentes despojos.

51 Sobre a localização deste acampamento e o local da batalha v., mais recentemente, Bellon et alii 2009 253-265.

52 Assim se interpreta geralmente o nome registado em Plb. 11.20.1 como Iligga e em Liv. 28.12 como Silpia.

53 Esta personagem, procônsul na Hispânia entre 205 e 201, acumula, segundo Liv. 31.20, o montante de 43000 libras de prata e 2450 de ouro, celebrando o triunfo que a tradição reservava a dictatores, cônsules e pretores. 
Em 197, com a criação de duas províncias na Hispânia, a Citerior e a Ulterior $^{54}$, dá-se início a um novo capítulo da presença romana neste território, agora com um outro estatuto e governado por magistrados regulares. Apesar disso, o clima de instabilidade foi-se acentuando nestas regiões só parcialmente controladas e em que a multiplicidade étnica e a sua tradição bélica, bem como as disputas territoriais tornavam mais crítica a situação. A gravidade desta conjuntura fica demonstrada pela chegada à Península de um dos cônsules, Catão, à frente de um exército considerável (195)55.

$\mathrm{Na}$ realidade a sua intervenção consistiu numa demonstração de força perante as populações locais, fragmentadas e sem possibilidade de oferecerem resistência a um poderio militar com esta envergadura. Catão, um tradicionalista, embora sem relegar a diplomacia, apresenta-se como um defensor de uma atuação dura. A sua estratégia não assegurou uma maior estabilidade no futuro, mas garantiu uma precária submissão de povos, enquanto a sua ação no domínio fiscal e da exploração mineira56 permitiu a Roma colher proventos de dimensão inédita.

Dos anos subsequentes conhecem-se algumas campanhas destinadas a consolidar a linha do Tejo, com ataques aos Carpetanos e seus aliados, que culminam com a tomada de Toletum (Liv. 35.22.5), e confrontos com os Lusitanos na Baixa Andaluzia. A cidade de Asta aparece várias vezes no centro dos conflitos com os Lusitanos: num deles perdeu a vida o pretor C. Atínio (Liv. 39.21.2-3); um ano antes, também o procônsul Emílio Paulo ${ }^{57}$ os deverá ter enfrentado, com sucesso ${ }^{58}$. A situação mantém-se crítica também na Citerior, província em que se deve assinalar especialmente a passagem de Tibério Semprónio Graco (180-179). Nela obteve alguns sucessos militares e diplomáticos, em particular no território celtibérico, conjugando as

${ }^{54}$ Sobre o processo da organização administrativa deste período v. González Román 1981 61-64.

55 Para a análise das fontes sobre as campanhas de Catão na Hispânia v. Martínez Gázquez 1992.

56 Martínez Gázquez 199275.

$57 \mathrm{Da}$ ação desta personagem nesta cidade conservou-se um interessante e precoce documento epigráfico (CIL II.5041) que concede a liberdade aos escravos de Hasta que habitarem na Torre Lascutana (/.../ quei Hastensium servei in Turri Lascutana habitarent /.../).

58 Chic García 198019. 
suas ações com o legado da Ulterior, L. Postúmio Albino ${ }^{59}$. A informação de que dispomos a respeito das movimentações militares nas próximas décadas é muito reduzida, pressupondo-se que, durante este período, Roma se preocupou mais em resolver outros problemas (internos ou de conflitos com outras regiões), mantendo-se a instabilidade, em particular entre Celtiberos e Lusitanos. Esta circunstância justifica que o senado lhe vá dedicar, a partir de determinado momento, uma maior atenção.

A historiografia antiga, seguida muitas vezes pela moderna, adota uma perspetiva romana, justificando geralmente todas as ações dos conquistadores e os seus fundamentos, passando com frequências para povos a responsabilidade pelos conflitos ou lamentando a falta de respeito por tratados, fronteiras e um conjunto de regras e tradições que, na sua perspetiva, distinguiam muitos hispânicos do "mundo civilizado". Este padrão de base greco-latina, todavia, não é compatível com tradições culturais hispânicas nem a sua perspetiva sobre a responsabilidade das guerras. $\mathrm{Na}$ base das ações romanas só pontualmente se apresentam explicitamente as suas intenções expansionistas, prevalecendo mais uma ideia de que os Romanos procuram garantir apenas a sua segurança e a dos seus aliados. O seu comportamento pauta-se pelas suas normas jurídicas e pela sua forma de entender as relações externas. Afasta-se, naturalmente, qualquer sentimento de que são intrusos num território de que se apropriam pela força das armas, subvertendo não apenas a geografia política, mas forçando igualmente a adaptação das populações às suas exigências.

É compreensível que autores gregos ou romanos, ciosos da superioridade da sua cultura, encontrassem justificação para a sua perspetiva; mas também se explica que a historiografia atual ensaie uma postura diferente, compreendendo as tradições locais e as graves consequências que a uma presença externa agressiva e não solicitada tinha para a sua estabilidade.

Estas questões, válidas de uma forma geral para todo o território, colocam-se a determinado momento a Lusitanos e Celtiberos, os quais, cada um a seu modo, se vêm confrontados com uma guerra total, movida por uma grande potência do Mediterrâneo.

59 Liv. 40.35 .7 ss.; 40.36.1-12; 40.39-40; 40.47-50; App. Hisp. 43. 
A resistência lusitana começa a ter um representante na figura de Púnico, um nome sugestivo ${ }^{60}$, que não pode desligar-se de uma tradição de presença de Cartagineses no sul da Hispânia e do facto de os interesses destes serem coincidentes com os das populações que se opunham aos Romanos. Apiano dá breve conta da sua ação vitoriosa sobre os pretores Marco Manílio e M. Calpúrnio Pisão, «matando 6000 homens entre eles o questor Terêncio Varrão»(App. Hisp. 56). Sucedeu-lhe Césaro que venceu Múmio, governador da Ulterior em 153, quando este «o perseguia de forma desordenada" (App. Hisp. 56). O mesmo historiador refere-se, de seguida, a Cauceno, chefe dos Lusitanos "do outro lado do Tejo" (App. Hisp. 57), que terão empreendido uma campanha que os conduziu ao território dos Cónios $^{61}$ (sul de Portugal) e à sua principal cidade, Conistorgis, tendo daí passado ao norte de África, onde foram destroçados por Múmio.

Desta forma, Apiano apresenta uma breve sequência dos chefes que precederam Viriato, o caudilho lusitano que vai marcar a resistência deste povo. A sua história, começa, segundo a tradição literária que nos foi transmitida por esse historiador grego, em 151, quando Galba, governador da Ulterior, procurava pôr termo às ações do "bandolerismo" lusitano, que tantos comentários negativos suscita nas fontes clássicas. Com uma ilusória promessa de terras, este teria dividido a população em três grupos, desarmados, aproveitando-se da boa fé deles para os massacrar ${ }^{62}$. Alguns escaparam, entre eles Viriato (App. Hisp. 60).

Depois de uma aparente acalmia, os conflitos reacenderam-se, já sob o seu comando, quando era pretor da Ulterior Gaio Vetílio (147), o qual

60 Parece estranho que fosse este o nome de uma personagem lusitana, pelo que seria viável admitir que o apelativo corresponderia a uma origem étnica, atribuível a um chefe militar, cartaginês, em cuja experiência e saber militar a entidade hispânica confiava.

${ }^{61}$ Esta é uma das poucas situações em que as fontes clássicas associam as guerras lusitanas a território atualmente português, uma vez que o teatro das operações se centra essencialmente no que vem a ser a futura província da Bética, grosso modo correspondente à atual Andaluzia (Chic García 1980; Pérez Vilatela 1989; Guerra 2001 85-89).

62 Em Suet. Gal. 3.2 refere-se que ele matou perfidamente 30000 lusitanos, naturalmente um número simbólico. 
foi capturado e morto, dando início a um período em que Roma perde o controlo da situação na província. Só em 145, com a chegada do cônsul Fábio Máximo, foi possível obter alguns sucessos militares e reduzir a instabilidade. Mas quando o exército consular retirou, os Lusitanos alargaram a sua influência a muitas cidades e territórios meridionais, até à Bastetânia. Depois do sucesso de Viriato contra Quíncio, governador da Citerior, em Ituci (143) e da derrota de L. Metelo (142), o exército consular, comandado por Q. Fábio Máximo Serviliano (141-140), procurou atacar os apoios de Viriato, inicialmente com bastante sucesso, mas seguindo-se uma derrota em Erisane, cidade que se toma como pátria do caudilho lusitano ${ }^{63}$. Este, desejoso da paz, aproveitou o momento para celebrar um pacto, tornando-se deste modo "amigo dos romanos" (App. Hisp. 69). O tratado foi, contudo, recusado pelo sucessor de Serviliano que, como sublinha Apiano, era o seu próprio irmão, Q. Servílio Cepião, autorizando o senado que este provocasse o inimigo "secretamente» (App. Hisp. 70).

Reacendeu-se o conflito e o general romano tomou Arsa, obrigando os Lusitanos e o seu chefe a empreenderem uma fuga para a Carpetânia ${ }^{64}$. Torna-se claro que Viriato foi sendo empurrado progressivamente para norte e já não possuía grande apoio, pelo que se viu obrigado a negociar. Os seus três representantes nestas negociações, segundo a tradição (D.S. 33.21) naturais de Urso (atual Osuna, Sevilha), deixaram-se corromper e assassinaram Viriato, pondo-se termo ao conflito desta forma inglória. Estes acontecimentos e a heroica resistência do caudilho lusitano alimentaram a literatura clássica, em especial Possidónio ${ }^{65}$, que o converteu num modelo, segundo os princípios da filosofia cínica ${ }^{66}$.

$63 \mathrm{O}$ texto (App. Hisp. 69) refere-se-lhe como a sua cidade (Erisanen autou polin), que alguns aa. (v. g. Schulten 1937 119, contra García Moreno 1989 38) identificam com Arsa, centro de operações lusitano em vários conflitos subsequentes.

64 Não deixa de causar alguma perplexidade a quem, seguindo a interpretação tradicional de que Viriato e os lusitanos teriam a sua origem no centro de Portugal, busquem refúgio num território tão distante. Há naturalmente, que afastar qualquer ligação entre Viriato e a Serra da Estrela, sem sustento em qualquer informação fiável (Guerra - Fabião1992 14-16).

65 A sua obra, em geral perdida, estaria na base do texto de Diodoro Sículo, que se dedica a descrever longamente as suas qualidades morais (Lens Tuero 1986)

66 Sobre esta perspetiva, v. Lens Tuero 1986. 
Se bem que já antes tivessem ocorrido alguns recontros com os Celtiberos, o início dos conflitos sistemáticos, que conduzem à conquista definitiva do seu território, tem o seu primeiro episódio em Segeda, "uma cidade dos Celtiberos chamados Belos, grande e poderosa" (App. Hisp. 44). Segundo a narrativa de Apiano, o pacto rompeu-se porque Roma entendia que Segueda o desrespeitava ao construir uma muralha mais extensa, destinada a albergar as cidades vizinhas, integrantes de uma liga celtibérica ${ }^{67}$; ao mesmo tempo o senado reclamava os impostos antes acordados e solicitava homens que reforçassem o seu exército (App. Hisp. 44). Os Segedanos procuram explicar a sua interpretação dos tratados, mas, porque os Romanos temiam o seu fortalecimento, não conseguiram evitar o início das hostilidades ${ }^{68}$. A campanha foi conduzida por M. Fúlvio Nobilior, o qual apanhou a cidade desprevenida, levando os seus habitantes a procurarem refúgio entre os Arévacos. Depois de acolhidos em Numância, "a cidade mais poderosa" (App. Hisp. 46), os Celtiberos prepararam um exército conjunto e obtiveram uma vitória, ainda que nessa ação perecesse o seu chefe, Caro. Um posterior ataque de Nobilior não foi mais feliz, devido, segundo a explicação de Apiano (Hisp. 46), ao descontrolo dos elefantes por ele envolvidos no ataque.

No ano seguinte as operações foram confiadas a Marcelo que adotou uma estratégia diferente e bem-sucedida frente a Ocilis e Nertobriga. Apiano (Hisp. 49) mostra que Marcelo privilegiou a diplomacia ao propor-se renovar o tratado de Graco, mas atribuiu-lhe igualmente cartas dirigidas ao senado recomendando a continuação do conflito, por desejar a fama. Independentemente disso, esta decisão põe em evidência o peso da fação mais belicista do senado, a qual deve ter sido já responsável pela orientação dada à questão de Segeda. Ao mesmo tempo, o historiador grego torna patente a sede de riqueza e prestígio, tanto de Marcelo como do seu sucessor. Foi esta que levou Marcelo a celebrar a paz com

\footnotetext{
67 Salinas $199699-102$.

68 Arce 198880.
} 
os Celtiberos (App. Hisp. 50) antes de chegar L. Licínio Lúculo (151). Foi também ela que justificou o alargamento da guerra aos Vaceus ${ }^{69}$; o seu pérfido comportamento em $\mathrm{Cauca}^{70}$; a reclamação, sem resultado, de elevados montantes de ouro e prata aos de Intercatia (App. Hisp. 53-54); o assédio a Pallantia, porque "era muito rica", acabando sem honra nem glória (App. Hisp. 55) ${ }^{71}$.

A situação em toda esta região manteve-se inalterada até 143, altura em que o apoio destes povos a Viriato (App. Hisp. 66 e 76) terá motivado o envio do cônsul Q. Cecílio Metelo Macedónico, episódio que dá origem ao que se designa como a "guerra de Numância"72. Depois de um início fulgurante com uma campanha vitoriosa contra os Vaceus, teriam restado por dominar apenas Numantia e Termantia ${ }^{73}$. Sucedeu-lhe Q. Pompeio Aulo (141-140), que se revelou incapaz de obter resultados positivos sobre estas duas belicosas cidades (App. Hisp. 76-78; D.S. 33.17). Depois de falhadas as diferentes estratégias para as submeter, procurou obter um acordo com Numância, que pudesse atenuar a dimensão do seu insucesso, mas o pacto viria a ser negado por Roma (App. Hisp. 79). O cônsul M. Popílio Lenas (139-138), não obteve melhores resultados (App. Hisp. 79) e, pior ainda esteve G. Hostílio Mancino (cônsul em 137), o qual, após sucessivas derrotas, foi obrigado a assinar uma paz que o senado mais uma vez não quis reconhecer ${ }^{74}$. Durante os três anos subsequentes as hostilidades contra Numância cessaram. No entanto, Emílio Lépido (137-136) atacou os Vaceus, contra as ordens do senado, e tendo posto cerco a Pallantia, foi derrotado. Foi, por isso, destituído do seu cargo e multado ${ }^{75}$.

69 Apiano comenta que esta guerra contra os Vaceus não foi sequer sancionada por Roma e Lúculo nem sequer foi julgado por isso (App. Hisp. 55).

${ }^{70}$ App. Hisp. 51-52; Arce 1988 86-87.

71 Roldán 2001 156-157

72 Sobre os conflitos v. Dobson 2008.

73 App. Hisp. 76. Esta cidade tem sido identificada com Termes (Tiermes, Soria) v. Schulten 1937 33, cujos habitantes se referem em Liv. Per. 54 como Termestinos.

${ }^{74}$ App. Hisp. 83; Cic. Off. 3.109; Rep. 3.28; Oros. 5.4.21; Eutr. 4.17; Flor. Epit. 1.34.4. Sobre o tratado v. Wikander 1976.

75 App. Hisp. 83; Arce 198891. 
A vergonhosa incapacidade dos Romanos perante Numância conduziu ao envio de P. Cornélio Cipião Emiliano para a Hispânia. Este começou por selecionar o exército, impor-lhe disciplina (App. Hisp. 85) e cortar as possibilidades de abastecimento da cidade com alguns ações em território vaceu, em particular nas áreas de Palantia e de Cauca. ${ }^{76}$ Aplicou-se igualmente numa atividade diplomática destinada a contar com o apoio de outras populações locais. Insistindo na ideia de que era preferível vencer os Numantinos pela fome do que combater com aqueles que provocavam confrontos esporádicos, foi poupando as suas energias e tornando cada vez mais crítica a situação da cidade. Para obter este resultado contribuiu a construção de um extenso fosso e uma paliçada que circundavam completamente o inimigo (App. Hisp. 86); cortou a passagem do rio, de forma a evitar o abastecimento e a passagem de pessoas ${ }^{77}$. As fontes descrevem a situação cada vez mais desesperada dos sitiados e as tentativas, nem sempre bem vistas, de alguns representantes numantinos negociarem a rendição ${ }^{78}$. Por fim, acabam por depor as armas e entregar-se, embora muitos tenham optado por pôr termo à vida. Os que se entregaram foram vendidos, depois de escolher cinquenta de entre eles, para a celebração do triunfo; as suas terras foram repartidas entre as cidades vizinhas que se juntaram à causa romana.

Mesmo que se exponha nos textos que nos chegaram uma visão parcial com intuitos propagandísticos e laudatórios ${ }^{79}$, transparece neles a admiração pelas qualidades de gente bárbara, que demonstra excecional bravura e preza, acima de tudo, a sua liberdade. Na perspetiva historiográfica das fontes clássicas, eleva-se a dignidade e o valor dos Numantinos, tornando mais sublime quem os venceu.

76 Wattemberg 1959.

77 Sobre o cerco Cipião e os seus acampamentos v., mais recentemente, Dobson 2008 e Jimeno Martínez 2001.

78 App. Hisp. 95-98; Flor. Epit. 1.34.14-17; Oros. 5.7.11-18 Sobre o impacto na tradição historiográfica desta resistência v. Jimeno; Torre, 2005.

$79 \mathrm{Na}$ base destas narrativas encontra-se, em boa parte, o texto de Políbio, admirador e protegido de Cipião, mas também um historiador que procura distanciar-se desse facto (Green 1990 277-285). Para uma perspetiva sobre a presença deste autor grego nesta campanha v. Sancho Royo 1973. 
Portanto, num curto espaço, Roma passa do controlo da Península Itálica ao domínio do Mediterrâneo. Torna-se patente uma evolução da sua política imperialista que começa por uma atitude que visava antes de mais garantir da segurança e proteção dos aliados, de acordo com os ditames da guerra justa, avança depois para um maior interesse pelo controlo, deixando embora uma certa autonomia no Oriente, para culminar na subjugação efetiva e aniquilação das resistências, como mostra a destruição de Cartago, de Corinto e de Numância.

\section{Tábua cronológica}

$229-1^{a}$ guerra ilíria

$219-2^{a}$ guerra ilíria

$215-1^{a}$ guerra macedónia

205 - Acordo de paz de Fenice

200-197 - 2a guerra macedónia

197 - Batalha de cinoscéfalas

196 - Acordo de paz de Tempe

192-189 - Guerra contra Antíoco III

189 - Batalha de Magnésia

188 - Acordo de paz de Apamea

171-168 - $3^{\text {a }}$ guerra macedónica

168 - Batalha de Pidna

154-133 - Guerras contra os Lusitanos e Celtiberos

148 - Criação da província da Macedónia

146 - Destruição de Corinto e Cartago

139 - Assassínio de Viriato

133 - Destruição de Numância

\section{Bibliografia}

Arce, J. (1988), Las guerras celtíbero-lusitanas in Blázquez, J. M. et alii, Historia de España antigua. Madrid, Cátedra, 79-98.

Austin, A. E. et alii ed. (1989), Cambridge Ancient History, volume VIII - Rome and the Mediterranean do 133 B. C.. $2^{\text {nd }}$ edition. Cambridge, University Press. 
Berthold, R. M. (1984), Rhodes in the Hellenistic Age. London, Cornell University Press (rep. 2009).

Derow, P. S. (1973), "Kleemporos”, Phoenix, 27 118-134

Dobson, M. J. (2008), The Army of the Roman Republic. The Second Century BC, Polybius and the Camps at Numantia, Spain. Oxford, Owbow.

Eckstein, A. (1994), "Polybius, Demetrius of Pharus and the Origins of the Second Illyrian War", CPh 89 46-59.

Fernández Rodríguez, D. (2005), "Toma de Carthago Nova por Publio Cornelio Escipión: leyenda o realidad?", Polis, 17 31-72.

García Moreno, L. (1989), "La Hispania anterior a nuestra era: verdad ficción y prejuicio en la historiografía antigua y moderna", Actas del VII CEEC, Vol. III, Madrid 1989 $17-43$.

Gebehard, E. R. - Dickie, M. W. (2003), "The view from the Isthmus ca. 200 to 44 B. C." in Williams, Ch. K. II \& N. Bookidis eds., Corinth, the centenary 1886-1996. Athens, American School of Classical Studies at Athens, 261- 278.

Grainger, J. (2002), The Roman War of Antiochos the Great. Leiden - Boston, Brill.

Green, P. (1990), Alexander to Actium: The historical evolution of the Helenistic age. Berkeley / Los Angeles, California University Press.

Gruen, E. S. (1984), The Hellenistic World and the Coming of Rome. Berkeley - Los Angeles, University of California Press.

Guerra, A. - Fabião, C. (1992), "Viriato: genealogia de um mito", Penélope, 8 9-23.

Guerra, A. (2010), "Acerca dos conceitos de 'lusitano' e 'Lusitânia'", Serta Palaeohispanica J. de Hoz: Palaeohispanica, 10 81-98.

Hammond, N. G. L. - F. W. Walbank (1988), History of Macedonia, vol. III, 336-167 B. C. New York, Oxford University Press (rep. 2001).

Hammond, N. G. L. (1968), "Illyris, Rome and Macedonia 229-205 b.C.", JRS 58 1-21.

Hammond, N. G. L. (1988), "The Campaign and Battle of Cynoscephalae (197 B. C.)", JHS, 108 60-82.

Harris, W. V. (1979), War and Imperialism in Republican Rome. Oxford, University Press.

Holleaux, M. (1930), Cambridge Ancient History: Rome and the Mediterranean; 218-133 B.C., (1st edition) Vol VIII. Los Angeles, Cambridge University Press.

Jimeno Martínez, A. - de la Torre Echevarria, J. A. (2005), Numancia, símbolo e historia. Madrid, Akal.

Jimeno Martínez, A. (2002), "Numancia: campamentos romanos y cerco de Escipión”, AEA, 75 159-176.

Kallet-Marx, M. (1995), Hegemony to Empire. The Development of the Roman Imperium in the East from 148 to 62 B.C. Berkeley, University of California Press.

Lens Tuero, J. (1986), "Viriato, heroe y rey cínico", Estudios de Filología Griega 2 253-272.

MacDonald, A. H. (1967), "The Treaty of Apamea (188 B. C.)", JRS 57 1-8.

Magie, D. (1939), "The 'Agreement' between Philip V and Antiochus III for the Partition of the Egyptian Empire", JRS 29 32-44

Matingly, D. J. (2011), Imperialism, Power and Identity. Princeton, University Press.

Pérez Vilatela, L. (1989), "Procedencia geográfica de los Lusitanos en las guerras del siglo II a. de C. en los autores clásicos, Actas del VII de CEEC. Vol. III. Madrid, 1989 257-262. 
Rauh, N. K. (1993), The Sacred Bonds of Commerce: Religion, Economy, and Trade Society at Hellenistic Roman Delos. 166-87 B.C. Amsterdam, J. Gieben.

Richardson, J. S. (1986), Hispaniae: Spain and the Development of Roman Imperialism, 218-82 BC. Cambridge, University Press.

Roldán Hervás, J. M. - Wulff Alonso, F. (2001), Citerior y Ulterior: Las provincias romanas de Hispania en la época republicana. Madrid, Istmo.

Roldán Hervás, J. M. (1988), "Cartago y Roma en la Península Ibérica; Las províncias romanas de Hispania hasta las guerras celtíbero-lusitanas" in J. M. Blázquez et alii, Historia de España antigua. Madrid, Cátedra, 15-77.

Salinas de Frías, M. (1996), La conquista y romanización de Celtiberia. Salamanca, Universidad.

Sancho Royo, A. (1973), "En torno al bellum Numantinum de Apiano", Habis, 4 23-40

Schulten, A. (1937), Fontes Hispania antiquae, IV. Barcelona Librería Bosch.

Scullard, H. H. ( $\left.{ }^{4} 1980\right)$, A History of the Roman World. London. Routledge (rep. 2007)

Walbank, F. W. (1963), "Polybius and Rome's eastern policy", JRS 53 1-13.

Walser, G. (1954), "Die Ursachen des ersten römisch-illyrischen Krieges", Historia 2 308-317.

Walsh, J. J. (1996), "Flamininus and the Propaganda of Liberation", Historia, 45 344-363

Wattemberg, F. (1959), La Región Vaccea, Celtiberismo y romanización en la cuenca media del Duero. Madrid, CSIC.

Wikander, O. (1976), "Caius Hostilius Mancinus and the foedus Numantinum", ORom, 11 85-104. 